| Research Article / Araştırma Makalesi |

Turkish Language and Culture Education in Flanders, Belgium: A model proposal ${ }^{1}$

\title{
Belçika Flaman Bölgesi’nde Türkçe ve Türk Kültürü Eğitimi: Bir Model Önerisi
}

\author{
Ebru Karataş Acer², N. Feyza Altınkamış3
}

\author{
Keywords \\ 1. Turkish Language and \\ culture \\ 2. Flanders, Belgium \\ 3. Educational Planning \\ 4. Institutionalism \\ 5. A model
}

Anahtar Kelimeler
1. Türkçe ve Türk
Kültürü
2. Belçika Flaman
Bölgesi
3. Eğitim Planlaması
4. Kurumsallaşma
5.Model Önerisi

Received/Başvuru Tarihi 27.10.2020

Accepted / Kabul Tarihi 27.04.2021

\begin{abstract}
Purpose: In this paper, "Turkish language and culture classes (TLCL) " in Belgium are chronologically presented from past to present and based on the challenges and problems faced, a case study was conducted. Furthermore, an integrated model is presented to address the problem of suspended and ill-structured Turkish language education in the Flemish Region

Design/Methodology/Approach: Since 30 June 2016, Turkish language and culture classes have been suspended in the Flemish Region of Belgium, a federal state composed of communities (Flemish, French, and German-language) and regions (Flemish, Walloon, and Brussels Capital), which makes it problematical for the Turkish community to keep its language and culture alive through classes. Since 2016, some local NGOs have been able to organise 'Turkish-language and culture classes' in the Flemish Region through programmes funded by the Presidency for Turks Abroad and Related Communities in Turkey. While this appears to be a short-term solution to the problem of suspended Turkish language classes at schools, a new model should be drafted in order to adopt an institutionalised and longitudinal school-based approach as a long-term solution.

Findings: For an effective Turkish-language and culture teaching and learning process, some important and sustainable measures should be taken into account. A negligence suspension after 2016 has affected Turkish-language and culture teaching and learning processes, heralding a period of regression. Pursuant to a Protocol signed by the Flemish Government and Turkish Government, TLCL were resumed in Flanders in the 2019-2020 academic year, with a model-based approach presented in this study.
\end{abstract}

Highlights: This educational model came about thanks to a theme-based, multilingual approach, which is integrated successfully in Flemish schools by bilingual, local teachers living in Flanders.

Öz

Çalışmanın amacı: Bu çalışmada, Belçika'da "Türkçe ve Türk Kültürü Dersi (TTK)" olarak ele alınan eğitim sürecinin geçmişten günümüze seyri ele alınmış ve bu süreçte yaşanılan sorunlara kronolojik olarak değinilerek bir durum değerlendirilmesi yapılmıştır. Ayrıca bu makale kapsamında, TTK eğitim sürecinde yaşanılan en önemli sorunların başında olan bu sürecin Flaman Bölgesi'nde devam edememesi sorununu giderebilmek üzere bir model önerisi sunulmuştur.

Materyal ve Yöntem: Kendi içinde üç farklı bölgenin olduğu (Flaman Bölgesi, Brüksel Başkent bölgesi, Valon Bölgesi) ve kendi iç işlerinde özerk olarak yönetilen federal bir ülke olan Belçika'da Flaman Hükümeti'nin kanun ve uygulamaları ile 30 Haziran 2016 tarihinden itibaren tüm Flaman Bölgesi'nde Türkçe'nin öğretimine yönelik Türkçe derslerinin verilmesi durdurulmuş ve böylece Türk kültürünün bu dersler ile öğretilmesinin önü kesilerek bu bölgede yaşayan vatandaşlarımızın kendi kültür ve dilini yaşatabilmesi çok daha zorlaşmıştır. 2016 yılından sonra Flaman Bölgesi'nde Yurtdışı Türkler ve Akraba Topluluklar Başkanlığı (YTB) destekli dernekler tarafından yürütülen projeler ile kısa vadeli süreç ilerliyor gibi görünse de sorun hala devam etmekte ve kurumsal bir yapı ile okula dayalı eğitimi öngören uzun soluklu çözüm önerilerine ihtiyaç duyulmaktadır.

Bulgular Türkçe'nin ve Türk kültürünün sağlıklı bir çerçevede öğrenilmesi ve etkin bir şekilde kullanılmasına yönelik oldukça önemli adımlar atılması gerekmektedir. 2016 yılından beri bir sürüncemede kalan bu eğitim öğretim süreci ciddi bir gerilemeye gitmiştir. Bu sorunları gidermek üzere Flaman Hükûmeti ve Türkiye arasında imzalanan ek protokolde anlaşmaya varılan noktalar dikkate alınarak, Türk makamlarının desteği ile 2019-2020 eğitim öğretim yılında, bu makale kapsamında geliştirilen yeni bir eğitim modeli ile Flaman Bölgesi okullarında Türkçe dersleri yeniden başlamıştır.

Önemli Vurgular: Bu eğitim modeli, Flaman bölgesinde ikamet eden ve istihdam edilecek öğretmenler tarafından ve tema temelli bir eğitim öğretim müfredatına dayalı olarak Flaman Bölgesi okullarına entegre olmuş bir model olarak tasarlanmıştır. Bu makale kapsamında Flaman Bölgesi’nde mevcut olan soruna çözüm önerisi olabilecek kurumsallaşmış bir TTK eğitim modeli geliştirilmeye çalışılmıştır.

\footnotetext{
${ }^{1}$ This study is funded by Republic of Turkey Ministry of Culture and Tourism, Presidency for Turks Abroad and Related Communities in Turkey.

${ }^{2}$ Corresponded Author, Ghent University, Faculty of Arts and Philosophy, Department of Translation, Interpretation and Communication, Ghent, BELGIUM; https://orcid.org/0000-0002-5780-2093

${ }^{3}$ Ghent University, Faculty of Arts and Philosophy, Department of Translation, Interpretation and Communication, Ghent, BELGIUM; https://orcid.org/00000002-5665-5394
} 


\section{INTRODUCTION}

In Belgium, "Turkish-language and culture classes (TLCL)" have been given by the Education Counsellor of the Turkish Embassy in Brussels through teachers appointed by Turkey. In Brussels and in Wallonia, these courses are still being given within the framework of the Openness to Languages and Culture Programme. In Flanders, however, these lessons cannot be given (see Table 1). As a federal state, Belgium is composed of three communities (the Flemish Community, the French-speaking Community, and the German-speaking Community) and three regions (the Flemish Region, the Brussels Capital Region, and the Walloon Region. As a result of the regulations followed and the decisions taken by the Flemish Government, TLCL was suspended on 30 June 2016. This was an obstacle for the children of Turkish origin to continue learning their own culture and language.

At a first glance, the abolition of TLCL stemmed from administrative and legal issues, rather than educational ones. As a result of the 6th state reform (Powers Reform), in Belgium, the power of work permit was transferred to regions. Then, the Flemish Government decided not to give work permits to anyone who does not live in this region and who does not pay social security. This signalled the end of TLCL in 2014. In line with this ruling, teachers appointed by Turkey were no longer granted a special residence permit (diplomatic residence permit) and these teachers were directed to municipalities where they lived to apply for their official residence permit, which was the process of receiving residence permit by all foreigners in Belgium. The first document, however, to be submitted in the application for an official residence permit is the declaration of one's work and pay slips given by an employer in Belgium. As these teachers were appointed by Turkey and as they received their salaries from Turkey, their official pay slips were not considered the proper documents. As a result, they could not complete the process of receiving official residence permits. In the academic year of 2014-2015, a protocol amendment was signed between the Flemish Government and Turkey and the teachers who had already been in Belgium at that time could work till the end of 2015, which was a temporary solution for these teachers. Following this, the second protocol was signed between the Government of Flanders and Turkey, agreeing on a new arrangement. According to this new ruling, the system of TLCL will be changed into a renewed approach in which TLCL will be given by members of the Turkish Community in Flanders. As this article is being prepared, no concrete action has been taken by either party (Altınkamış, 2019).

In the academic year of 2017-2018, TLCL began in different non-governmental organisations in the framework of the Anatolian Weekend Schools/Turkish Time programme of the Presidency for Turks Abroad and Related Communities in Turkey. Today, these programmes are still running. In addition, in the academic year of 2018-2019, two teachers of Turkish origin, who are official residents in Belgium and teaching in Belgian schools, started to TLCL in their schools as extracurricular activity in Ghent and Houthalen, which was again supported by the Presidency for Turks Abroad and Related Communities in Turkey. It seems that the projects supported by the Presidency for Turks Abroad and Related Communities in Turkey offer temporary and short-term solutions. New models, however, should be designed for a holistic and institutional process, because the current position of TLCL should also be analysed in terms of educational aspect besides political, legal, and administrative aspects in order to gain a holistic educational perspective.

Another important point related to TLCL is the curriculum. Today, teaching materials based on the educational programme in Turkey is mainly followed by monolingual Turkish teachers. These materials do not address the current needs of Turkish-Dutch bilingual children. For these reasons, a new educational programme and curriculum are urgently required to provide an effective framework and a better planning and to solve the current problems.

Serious steps should be taken to teach Turkish language and culture in an efficient way. Owing to the problems which cannot be solved, and which block the process, teaching and learning Turkish language and culture have suffered. As an answer to these problems, in this article, an institutionalised TLCL model has been developed and introduced. This model aims to embrace all decisions agreed by both parties in the 2 nd protocol, namely teachers who are official residents in Flanders (to be employed by the Flemish Government in the long run), a theme-based curriculum integrated in the official curriculum adopted in Flemish schools. This model was followed by the Institute for Turkish Studies, Integration and Research in the academic year of 2019-2020 as a pilot project. This article aims to present the rationale, planning and the implementation process of this project. In addition, suggestions will be given for the future of TLCL in Flanders. 
Table 1. The background of Turkish Language and Culture Education in Belgium

\begin{tabular}{|c|c|c|}
\hline Date & Chronological Phases & Explanation \\
\hline 29 December 1958 & The cultural agreement signed between Turkey and Belgium & \\
\hline 16 July 1964 & The bilateral labour agreement between Turkey and Belgium & \\
\hline 1977 & $\begin{array}{l}\text { The programme "Mother Tongue and Culture" was replaced by the programme } \\
\text { "Openness to Languages and Cultures", following the EU regulation in } 1977 \\
\text { Teachers appointed by Turkey started to give Turkish language classes in different } \\
\text { associations working in close collaboration with the Turkish community. }\end{array}$ & $\begin{array}{l}\text { The general objective of Turkish mother tongue classes in that period } \\
\text { was based on the fact that immigrants of Turkish origin were } \\
\text { guestworkers and they would eventually return to their home country. } \\
\text { Therefore, they were not encouraged to to maintain their mother } \\
\text { tongue and culture. }\end{array}$ \\
\hline $1980-1990$ & Milder actions & $\begin{array}{l}\text { For example, the municipality of Ghent employed teachers to give } \\
\text { Turkish language classes. }\end{array}$ \\
\hline 1997 & $\begin{array}{l}\text { The programme "the openness to languages and cultures" followed in Wallonia and } \\
\text { in Brussel continued between the period of 1997-2000, including Greek, Turkish, } \\
\text { Moroccan, Portuguese, and Italian children. }\end{array}$ & \\
\hline 2001 & $\begin{array}{l}\text { This programme was renewed and used between the period of 2001-2005. It was } \\
\text { changed into the format of a bilateral agreement and ran between 2006-2009. }\end{array}$ & $\begin{array}{l}\text { Romania was included in this programme in 2008, Spain in } 2009 \text { and } \\
\text { China in } 2011 .\end{array}$ \\
\hline $\begin{array}{l}2014-2015 \\
\left(1{ }^{\text {st }} \text { protocol }\right. \\
\text { amendment: } \\
23 / 12 / 2014)\end{array}$ & $\begin{array}{l}\text { The 1st protocol amendment signed between the Republic of Turkey, Turkish } \\
\text { Embassy in Brussels (Ambassador Hakan Olcay) and the Flemish Minister of } \\
\text { Education (Hilde Crevits) (the period of validity: 1/9/2014-15/07/2015) }\end{array}$ & $\begin{array}{l}\text { This protocol amendment only affected the academic year of 2014- } \\
\text { 2015. At that time, there were } 8 \text { teachers appointed by Turkey in } \\
\text { Flanders. }\end{array}$ \\
\hline 15 July 2015 & The end of the $1^{\text {st }}$ protocol amendment & $\begin{array}{l}\text { The end of the appointment of Turkish and Turkish culture teachers by } \\
\text { Turkey }\end{array}$ \\
\hline
\end{tabular}

\footnotetext{
${ }^{4}$ Based on an interview with the Republic of Turkey, Turkish Embassy in Brussels (17 June 2019).
} 


\section{Date}

17 July 2015

\section{Chronological Phases}

The 2nd protocol amendment signed between the Republic of Turkey, Turkish Embassy in Brussels (Ambassador Hakan Olcay) and the Flemish Minister of Education (Hilde Crevits)

(Memorandum of Understanding)

After the period of $30 / 6 / 2016$

2017-2018

No Turkish language and Turkish culture classes in Flanders (outof-school-hours)

Two projects (Turkish Language and Culture, History, Religion, Arts) were started by two local NGOs in collaboration with the Presidency for Turks Abroad and Related Communities in Turkey under the programme of Anatolian Weekend Schools.

'The project: From Home Language to School Language'

2018-2019

Turkish Language and Culture classes in progress through projects by NGOs and financed by the Presidency for Turks Abroad and Related Communities in Turkey as part of the programme of "Turkish time".

2019-2020

"Teaching Turkish through a thematic approach in Flemish schools" was started in pilot schools out of school hours in Flanders. This project was financed by the Presidency for Turks Abroad and Related Communities in Turkey

2020-2021

"Teaching Turkish language through a thematic approach in Flemish schools" funded by the Presidency for Turks Abroad and Related Communities in Turkey is in progress as extracurricular activity.

\section{Explanation}

This only covered the period of 17/07/2015-30/6/2016. Teachers appointed by Turkey received their residency permits by following the official procedures in municipalities where they lived.

Turkish Language and Culture, history, religion, and arts classes were given as part of the programme of "Anatolian Weekend schools" financed by the Presidency for Turks Abroad and Related Communities in Turkey.

Turkish Language and Culture classes were given within the framework of a scientific project supported by Ghent University and the Ghent municipality and in collaboration with the Education Department of the Turkish Embassy in Brussels. This was a project in which bilingual instruction was provided to children aged 5-12. This project was not allowed in the academic year of 2018-2019 because of political discussions in the Flemish Government.

Turkish Language and Culture classes were given within the framework of "Turkish time" by different NGOs and in collaboration with the Presidency for Turks Abroad and Related Communities in Turkey and two teachers of Turkish origin in Ghent and in Houthalen as an extracurricular activity.

Turkish and Turkish Culture classes were given by the Institute of Turkish Studies, Integration and Research within the framework of collaboration with the Presidency for Turks Abroad and Related Communities in Turkey in 6 pilot schools. The classes were given by the teachers who were official inhabitants of Belgium and through a programme prepared in line with the Flemish educational thematic programme. Also, different NGOs organised Turkish Language and Culture classes in collaboration with the Presidency for Turks Abroad and Related Communities in Turkey as part of the programme of "Turkish education".

The project held by the Belgian Institute of Turkish Studies, Integration and Research is in progress in 8 pilot schools. Also, different NGOs organise Turkish-language and culture classes supported by the Presidency for Turks Abroad and Related Communities in Turkey as part of the programme of "Turkish education". 
In the process of two-sided socialisation, Turks living abroad go through integration phases into the host society, while protecting their own identity. This brings different cultures and different identities together. The heterogeneous situation based on these differences presents struggles, problems, and difficulties. Language maintenance is at the top of the struggles that Turks living abroad face. Drastic steps should be taken to maintain the Turkish language. Considering the fact that $4^{\text {th }}$-generation Turks live in Western Europe today, transmission of mother tongue and culture from one generation to another requires more attention. Following the bilateral labour agreement in the 1960s, the number of Turkish people reached a considerable level, sufficient to make their voices heard in the society where they live. However, as the Turkish community fails to make its demands known in a structured way to the ruling government, this need has become a problem. The current situation of TLCL exemplifies this.

\section{The Suspended Turkish-Language and Culture Classes (TLCL)' in the Flemish Region}

Since 30 June 2016, the TLCL have been suspended in the Flemish Region of Belgium, a federal country where this education continues as an extracurricular activity in schools with teachers coming from Turkey. Since the $6^{\text {th }}$ State Reform (Powers Reform), passed in 2012, the power of work permit was transferred to regions. Then, the Flemish Government decided not to give work permits to anyone who does not live in this region and who does not pay social security. This signalled the end of TLCL in 2014 because teachers coming from Turkey have no right to get residence/work permits. This delegation of power turned the state and local authorities into key decision-makers in authorising the power of residence/work permits. Yet, some alternatives have been discussed that TLCL can be organized as an extracurricular activity in schools with local Turkish teachers living in Flanders. As local authorities, like municipalities and school principals, they also play a key role in authorising their schools for this alternative. This local permission is not as easy as it seems, because it requires the approval and support of the TLCL. This local subjective permission for TLCL affects the process and compromises access to education for all. These TLCL should be well structured and planned not through subjective permission but in a scientific-objective manner.

\section{Decreasing Demand for the Turkish Language and Culture Classes (TLCL)}

In Western Europe, however, an inconsistent demand for TLCL has been observed among the Turkish community. Regarding the field research of this study and the observations/experiences of the authors, demand by the Turkish society for these classes are inconsistently changing either in a positive or a negative sense. The Turkish community's lack of response, however, amid suspended TLCL in the Flemish Region is remarkable, to say the least. Furthermore, the recent sharp decline in the numbers of students in TLCL given in the Flemish Region draw the attention (Sarıkaya, 2014).

\section{Bilingualism and Academic Success}

Language and cognitive development are related to the school success of bilingual children. According to Cummins (1979), it is highly crucial for bilingual children that a basis in their L1 be provided in order for them to experience the positive influence of bilingualism on their cognitive development. In line with Cummins (1979), Yağmur (2014) mentions that this basis functions as a linguistic and cognitive threshold (Yağmur, 2014). According to threshold theory, a bilingual child should attain the first threshold level in both languages in order to derive the maximum benefit from bilingualism. Following this, it can be said that it is crucial for children of Turkish origin to follow a parallel language development both in Turkish and in Dutch.

In studies analysing language skills in Dutch, systematic academic failures of children/students of Turkish background have been repeatedly shown in the studies. Belfi et al. (2014) observed Turkish children's low achievement in spelling and reading skills throughout primary school education in comparison to other ethnic groups in Flanders. Similarly, Vanbuel et al. (2016) concentrated on 6-year-olds of Moroccan and Turkish origin and compared them in terms of novel vocabulary learning. According to their results, children of Turkish origin were worse than their Moroccan peers in acquiring novel object labels and in understanding the story line. A recent study was conducted by D'Haeselaar et al. (2016), where a comparison was drawn between Turkish-Dutch six-year-olds bilingual children and Dutch monolingual peers through CELF-4, a test for early language development. They, too, found that the Turkish-Dutch sequential bilingual children in their study showed lower results when they were compared to their Dutch-speaking monolingual peers and other non-Western immigrants.

There are also studies addressing the Turkish language skills of Turkish-Dutch bilingual children. In particular, a recent study, conducted by Akoğlu and Yağmur (2016), focused on Turkish immigrant children's L1 development. In their study involving 30 bilingual Turkish-Dutch children and 30 monolingual Turkish children around 6 years old in the Netherlands, they found that Turkish immigrant children were not as successful as their monolingual peers in terms of L1 skills. In addition, it has been noted that socio-pragmatic skills of eight-year-old bilingual children of Turkish origin are not at the same level as those of their agematched monolingual peers (Backus and Yagmur, 2019). They suggested that these lower skills in their L1 may lead to lower skills in their L2. Bezcioglu-Goktolga (2016) carried out a study with 24 Turkish-Dutch bilingual children between 5 and 8 years old in the Netherlands. Focusing on this group of children's home language skills in comparison to Turkish monolinguals, she observed that Turkish-Dutch children performed poorly on several Turkish language tasks such as word definition, word order repetition 
and grammaticality judgment. Following these findings, it seems important that children of Turkish origin should develop their Turkish language skills as well as their language skills in Dutch to reach a threshold in both languages, in a manner that sufficiently supports their Dutch school programme. As a result, it can be said that the content of TLCL should be revised to meet Turkish language needs of the children of Turkish origin who are the 4th generation today in Western Europe. The findings of the related research should be taken into consideration to renew the content of TLCL. Well-prepared bilingual education programmes should directly aim at children's language proficiency and indirectly at increasing their school achievement. By doing so, it may be possible for children of an immigrant background to be better achievers at school and not to be guided to vocational high schools (Yağmur, 2014). In this suggested TLCL model in this article, it is also recommended that students' language development should be monitored by means of regular tests and should be supported by future-oriented applications.

According to the linguistic interdependence hypothesis by Cummins (1979), a high attainment in language skills in the first language will support a similar pattern in the second language. Despite the structural differences between languages being acquired, Cummins mentions similar linguistic and cognitive characteristics underlying all languages. Considering Cummins' approach, this model aims to support Turkish-language development of children of Turkish origin, which will also contribute to their language development in Dutch. This transfer between Turkish and Dutch constitutes an important rationale for Turkish language education today. As such, we have achieved a programme with a renewed perspective which matches the conditions agreed on the second protocol signed by the Turkish Government and Flemish Government and which provides a solid scientific and educational base.

Beyond the studies on the language development of Turkish students, many studies and reports show that the academic performance of immigrant Turkish students are below the average of the OECD countries. According to the OECD report (2009), the main problems of Turkish immigrants are a) the low attendance in pre-school education, b) acculturation and communication problems due to not using their mother tongue fluently, c) not having academic expectations and problems in the formal language acquisition of the host country due to the school's segregation, d) language and behavioural problems due the language barrier and high enrolment numbers in special education and programmes, e) high school dropout rate, f) unemployment rate of youths graduated from high school and vocational school, g) self-efficacy and identity problems about cultural differences and discrimination, h) negative altitude of the teachers towards immigrant students, i) negligence on the part of the parents and not having parent involvement in the school environment, j) lack of institutionalised integration and guidance centres in host countries that give immigrants special care.

According to the OECD report on PISA (2015) results on the immigrant academic performance of first-generation immigrant students (foreign-born students whose parents are also both foreign-born) and second-generation immigrant students (students born in the country/economy where they sat the PISA test and whose parents are both foreign-born), in most countries, both firstand second-generation immigrant students tend to perform worse than students without an immigrant background. According to the data on immigrant students' performance in science, by country of origin and destination', PISA (2015) results indicate that the performance of second-generation immigrant students from Turkish-speaking countries living in Sweden and Germany is higher than the first-generation immigrant students. However, there is no significant difference between the second- and firstgeneration Turkish immigrant students in Belgium. This finding shows that both $1^{\text {st }}$ and $2^{\text {nd }}$ generations of Turkish immigrants in Belgium have some problems in academic performance when there are relatively large immigrant student populations.

PISA results (2018) show that Turkish students in Europe are not successful at reading comprehension, mathematics, and science literacy. PISA results revealed that there is indeed an achievement gap between native speaking (NS) students and language minority (LMi) students for both reading and mathematics. After taking account of students' background characteristics, students' academic profiles and school characteristics, the LMi-NS achievement gap narrows but remains significant. However, the reason for the underachievement of LMi is not their language use. LMi students who speak a minority language more often with their parents do not achieve less. On the contrary, speaking a minority language more often with the father is positively related to mathematics and reading achievement of LMi students [Agirdag, O. (2016); Agirdag, O. \& Vanlaar G. (2016)].

To achieve academic development, we need to improve the mother-tongue language skills of Turkish students having problems in reading literacy. Some research (Rauch, Naumann \& Jude, 2012; Reich, 2011; Knapp, 1997; Verhoeven, 1994) shows that Turkish language education at schools have a positive effect on students' reading literacy and writing skills (Yıldız \& Thomas, 2016). Beyond these studies, it is thought that Turkish language education at schools would contribute towards students' academic performance as well. The content and curriculum of the Turkish language education is ideally integrated into the Flemish school system, culture, and environment. With a theme-based curriculum that is compatible with the school curriculum, TLCL can be used as a tool to reinforce the themes in their mother tongue parallel to the school context and curriculum in order to improve their learning. The key principle of a theme-based curriculum in Turkish mother-tongue language is to choose the themes parallel to the current curriculum of pilot schools in this study and to coordinate each theme interrelatedly for conceptual development. With this two-sided method, students can develop not only their mother-tongue language skills, their vocabulary and grammatical syllabus but also their academic performance at their own schools. Especially at pre-school level, this early-age follow-up and curriculum design would give immigrant students a chance to be schooled like bilinguals with no social and educational setbacks in Western European countries. This can also contribute towards the development of Belgian society. 


\section{METHODOLOGY}

The first part of this study was designed according to the needs obtained from the field research and the core principles of a phenomenological research design with a view to investigating a phenomenon of "Turkish-language and culture classes (TLCL)". In phenomenological research design, data sources are the groups or individuals who experience this phenomenon and can reflect on this phenomenon to others. The reasons to choose this design is a) to conduct more in-depth research into a phenomenon of TLCL because a phenomenological study explores what people experience and focuses on their experience of phenomena; $b$ ) to focus on phenomena of which we do not have a deeper and holistic understanding. In summary, phenomenological research design provides a suitable research ground for studies that aim to investigate phenomena that are not completely unfamiliar to us, and which we do not fully understand (Yıldırım \& Şimşek, 2004).

In the second part of the study, a case study design through an educational model was developed as a qualitative research method. A case study is defined as a study of a process that reveals perceptions and events using qualitative data collection methods such as observation, interview, and document analysis in a realistic and holistic manner in the natural environment (Yin, 2017). A model was developed for the Turkish-language and culture education through document analysis. Regarding the themebased curriculum prepared in line with the developed educational model, a field study was carried out on the basis of interviews with the relevant persons (relevant Embassy, Consulate General, Education Counsellor and Municipal Council Members, General Director of Education, etc.). Also, the case study design, rather than just collecting data, allows us to evaluate TLCL as a case, to examine a situation in-depth, to systematically reveal existing problems and to offer suggestions for solving the problems. In such studies, the main purpose is not to make generalisations about the universe, but to reveal the information about the existing situation in detail and to contribute to the future studies in the light of qualitative data obtained (Yıldırım \& Şimşek, 2005).

\section{The Education Model}

In the 21st century, it has become quite necessary to design an educational environment where different education models are juxtaposed. In today's world where different institutions can survive in societies with different educational institutions and different identities, there should be different models at the same time instead of insisting on a single model. From this point of view, a new model is needed for "Turkish-language and Culture education in Belgium". This process should be planned with a holistic perspective through pilot studies during the implementation phase because the environment and social structures of schools in different regions (such as Flemish, Brussels, Wallonia) should be taken into consideration.

In this study, since the protocol was signed between the Turkish Government and Flemish Government ${ }^{5}$, an educational model has come about thanks to a theme-based, multilingual approach, which is integrated successfully in Flemish schools by bilingual, local teachers living in Flanders. This new model was designed in an ecosystem based on key principles, goals, missions and visions and a philosophy. With a data-based system, relevant data were collected, and a data-driven process was launched. This education model has been planned in a holistic manner in order to integrate it into the Flemish education system and eliminate the existing problems. Pilot schemes, however, were determined and implemented on a small scale in the implementation phase. In the Flemish Region, it is planned that as a case study, the education model (See Figure 1) will be carried out with pilot schools before it is disseminated throughout the region in line with the measurement and evaluation process.

The education model has been designed based on data, which enables in-depth analysis of TLCL tailored to the needs determined by the field research. This method a) enables us to make objective evaluations for past decisions and realistic plans, b) includes various data and makes the data relevant in terms of cause-and-effect relationship, c) enables us to evaluate the pilot studies and to measure the process scientifically with a case-study approach. This process allows us to analyse and evaluate the data which have been available in the relevant institutions but could not be processed or not yet be obtained. In addition, the education model will be carried out on the intersection of the 'monitoring and evaluation process' and will progress at a certain level in an interdependent manner. Based on this model, the process is planned according to the academic performance of the students, curriculum design, the needs analysis and the professional development of teachers and students.

\footnotetext{
${ }^{5}$ Based on interviews with the Republic of Turkey, Turkish Embassy in Brussels (24 September 2018, 7 December $2018 ; 20$ February 2019; 29 May 2019; 17 June 2019; 3 July 2019).
} 


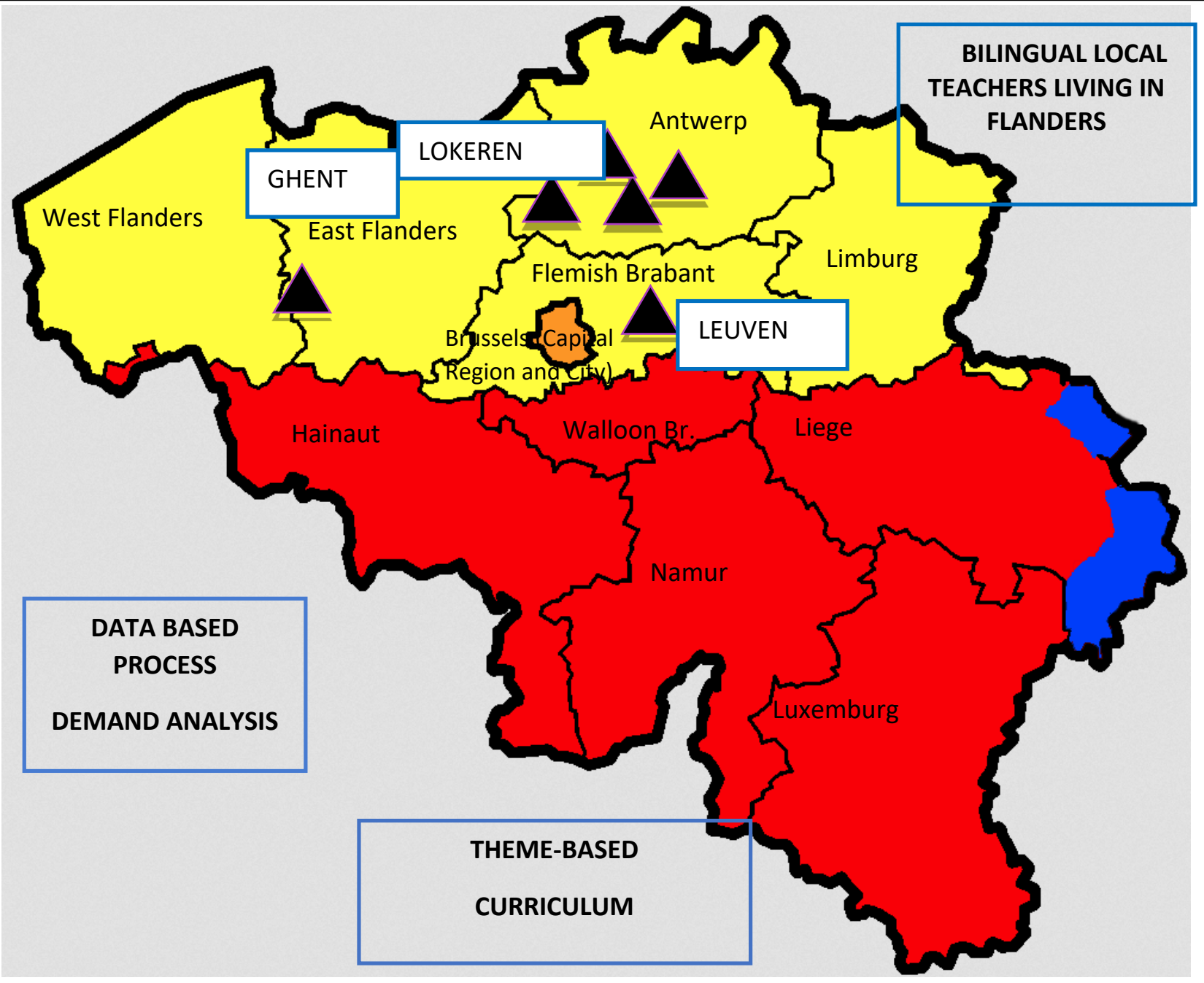

ORGANISATIONAL MODEL
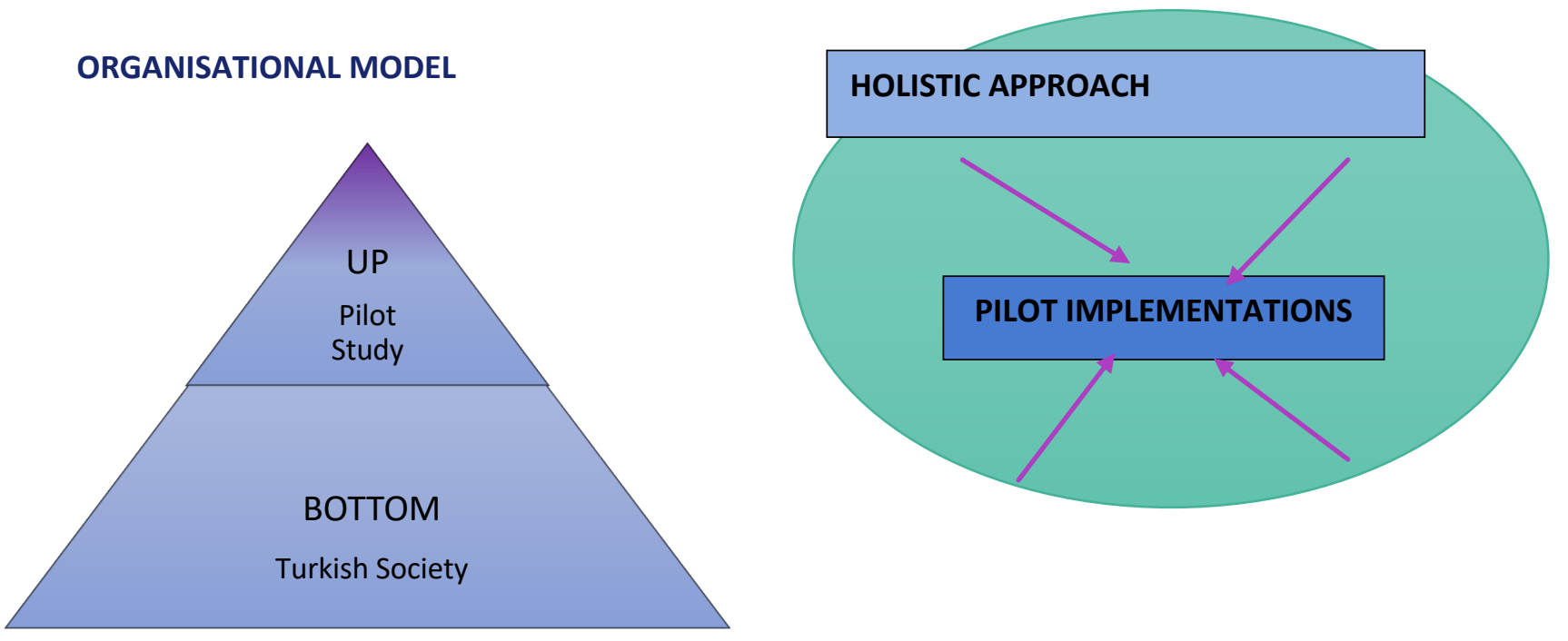

Figure 1. The Education model designed for the Turkish-Language and Culture Education in the Flemish Region 


\section{Study Group}

The sample of the study was selected by a specific sampling method and includes schools in cities (Lokeren, Ghent, Leuven) where there is a high demand for TLCL, and teachers who can be employed in the Flemish Region of Belgium.

The selection criteria;

- Approval of TLCL by school administration,

- Location in cities or regions with high demand for TLCL

- School culture which is sensitive to issues, such as immigration and bilingualism.

The criteria for teachers include,

- Individuals who have a teaching profession and a residency in Belgium,

- Teachers who had worked in Belgium before through institutions in Turkey,

○ Bilingual (Turkish-Dutch) teachers residing in Belgium.

\section{Implementation Process}

The education model built on a theme-based curriculum was carried out by 8 teachers in six pilot schools consisting of classes of 10-15 students aged 6-9, 9-12. These schools where teachers work, or can work, were determined according to the approval of the school administration. This education model was planned in a holistic manner so that it can be integrated into the Flemish education system and address the existing problems. The pilot study 1) can be tested, 2) can be micro-inspected, 3) can create a more reliable scientific basis for further assumptions, and 4) its weaknesses can be identified and eliminated.

In this model, six schools were chosen purposefully according to the sample criteria. These pilot schools include schools that authorise these classes and were selected based on the cities (Lokeren, Ghent, Leuven) where there is a high demand ${ }^{6}$ for TLCL. This educational model is planned with a theme-based curriculum integrated successfully into Flemish schools by bilingual local teachers living in Flanders. The data-based process includes the determination of the pilot schools, cities and teachers and the analysis of the demand of Turkish society.

In this model, Turkish society is at the bottom of the process and it has been planned with a bottom-up organisational model based on pilot implementations that intend to activate this bottom section. The bottom section of this organisational model is peopled by Turkish parents demanding TLCL. It is expected that families who demand TLCL are placed at the bottom of this organisational model and the combined demand present in the bottom section will affect this pilot study.

TLCL were planned according to the theme-based curriculum in pilot schools. In this education model, the theme-based curriculum is planned according to the weekly themes taught at the pilot school. In order to determine the themes, "Bingel Online Education Platform ${ }^{7 "}$, which is widely used in the Flemish Region, was taken as a basis. Through this online education platform, weekly themes were selected and analysed according to the level of the students and these themes were taught at the TLCL. For example, if the theme for that week was 'Family', this theme was taught to students in Turkish and in order to create a TurkishDutch vocabulary in the family theme, attention was drawn to the similarities and differences between the two cultures on the theme of family. After each theme, a curriculum blended with bilingual activities was planned by means of a list of Dutch and Turkish vocabulary for the relevant themes. The most important advantage of the theme-based curriculum is the support it offers the Turkish students in their conceptual development and the improvement of their Turkish and Dutch language skills in a way that affects their academic performance. Language-level tests are held at the beginning and the end of this pilot implementation, where the levels of the students will be evaluated. During the pilot implementation period, internal controls are in place, with reports written quarterly. To ensure the content validity, a control group consisting of the principals, the teachers teaching the course, the Turkish teachers and the field experts involved in pilot schools. Thus, the process was evaluated in terms of the content.

\section{DISCUSSION AND FURTHER IMPLICATIONS}

In Belgium, Turkish Language education is not structurally grounded for political, legal, and policy-related reasons on the part of the Turkish and Belgian authorities and is unable to answer the 21st-century needs. PISA reports and studies reveal the academic failure of Turkish children in Belgium (OECD, 2016). Current policies and practices are unable to solve this problem. Although the process seems to be helped by short-term projects by the Presidency for Turks Abroad and Related Communities in the Flemish Region, the problem still persists, and further measures are called for. In the Walloon Region, it is not known what kind of procedures will be carried out when the cultural agreement signed between the two countries (Belgium-Turkey) expires. For legal and political reasons, the Turkish community is required to find its own solution to this problem. However, the best way of addressing the legal and political problems is to plan this two-sided education effectively and scientifically. By conducting

\footnotetext{
${ }^{6}$ This demand was measured according to the data collected in 2019 by the Bureau of Education Consultancy at Turkish Embassy in Brussels.

${ }^{7}$ https://www.bingel.be/bingel/
} 
holistic evaluations of this process, national and international reports should be examined, and the education process should be planned with an institutional perspective. In order to solve this problem, setting up an institutional body such as "the Institute for Turkish Studies, Integration and Research" is a step in the right direction, but it is very important for both countries to come together in order to build a structural body. It is necessary to raise the awareness among all participants and to plan all the components of the process.

In order to meet the needs of the 21st century, TLCL in Belgium should be integrated into Belgian schools and transformed into a structure that can respond to existing changes. Schools are institutions with institutional environments (relevant stakeholders, municipalities, families, citizens, other schools, universities, NGOs, and local / national / international initiatives, etc.). The institutionalised environment defines the environment of an institution, where the environment and the institution are mutually affected by each other. The environment of an institution is the people or organisation with which they interact, with the institution's input. In order for schools to adopt TLCL, this process should be associated with the institutional environment of the schools. Schooling cut off from its institutional environment cannot survive in the long term.

From an institutionalist perspective, Aypay (2003, p. 111) stated that "environments and organizations are mutually constitutive. Both environments and organizations can give form, legitimize, and constrain". If organizational practices and policies readily become institutionalized; they become widely accepted as legitimate to attain organizational goals (Meyer and Rowan, 1977; Meyer and Scott, 1983; Tolbert, 1985). Organizations adapt their structure and behaviour to be consistent with the institutional environment in order to ensure their legitimacy and, hence, their chances of survival (Meyer and Rowan, 1977; DiMaggio and Powell, 1983). The legitimacy of the organization affects its ability to obtain resources and social support (DiMaggio and Powel, 1983; Tolbert, 1985). The organization refers here to the 'school', and schools and its educational activities include the socially defined rules and regulations required by the institutional environment (Scott, 1991, p. 167). With regard to the claim that schooling cut off from its corporate environment cannot survive in the long term, TLCL in Belgium could not be entirely organized within the NGOs in a closed system within Turkish society, but within the school, which is an open system, a system that can be integrated into society. This is the reason why we need to widen this process through the schools in the Flemish Region.

Regarding the planning and implementation of TLCL in Belgium - both in the past and present - it is also very important to pour this new education model into an institutionalised base, one which aims to solve the existing problems, and which has not been done before in the Flemish Region of Belgium. The key principles, goals, mission and vision and a philosophy of this education model should be shared among all stakeholders (Turkish Government, Flemish Government, municipalities, related NGOs, schools, and universities etc.). The job descriptions and responsibilities of the teachers who will take part in the pilot implementation of this education model should be clearly defined. In order to avoid possible problems in future, an accountable decision-making culture within the educational model is in the making. To create an independent 'school culture' in these pilot schools, a corporate school culture should be fostered with regular meetings, seminars, and social events.

It is also very important that this education model is sustainable. Based on the results of the pilot implementation, it is necessary to increase the number of pilot schools and the qualified teachers and scale up this process. By sharing the results of the pilot implementation with other schools, the number of schools that will approve this education can be increased and the education can proceed as planned. In addition, accountability and transparency benefit this education model greatly from an organizational perspective. The process will be internally supervised and monitored so that the relevant reports can be evaluated to ensure internal control. The evaluation processes of the monitoring and internal control groups will be regularly updated and shared with the relevant stakeholders. Sharing evaluation reports, especially with the Flemish Region authorities and relevant authorities, will enable us to build a transparent and accountable education process. In order to maintain the institutional philosophy and principles, there should be a constant dialogue with the relevant authorities.

One of the main reasons for suspending Turkish language education in recent years is that these courses can be a language barrier for the students' Dutch language skills and teaching only Turkish language after school will create an inequality in education access for other immigrants. Also, some PISA reports have claimed that native-speaking (NS) students outperform language minority (LMi) students. Many policymakers have responded to these PISA reports with a monolingual reflex by increasing political pressure on linguistic minorities to abandon their heritage languages (Agirdag, 2010; Pulinx, Van Avermaet \& Agirdag 2016, as cited in Agirdag, O. (2016); Agirdag, O. \& Vanlaar G. (2016). In line with these arguments, this educational model is not only planned to teach Turkish language for Turkish students. It is planned so that the Turkish language education model will create a two-way effect with a theme-based curriculum that supports the academic achievements of Turkish students at Flemish schools. The most important advantage of the theme-based curriculum is that Turkish students can gain academic competence by improving their school achievements. The most important part of this education model is that it can measure the academic accomplishments of students with a data-based evaluation process and provide future assumptions. Furthermore, studies do not support the assumptions that TLCL can be a language barrier for the children's Dutch language skills. Contrary to these assumptions, some research (Rauch, Naumann \& Jude, 2012; Reich, 2011; Knapp, 1997; Verhoeven, 1994) shows that Turkish language education at schools has a positive impact on students' reading literacy and writing skills (Yıldız \& Thomas, 2016). With these, and similar, scientific outputs, widespread political thinking in the Flemish Region of Belgium about Turkish language education should be criticised. At this point, it is necessary to be accountable and to present scientific studies to the relevant authorities. As a result of the meeting with the relevant authorities, the education model for Turkish language education was 
explained and met with positive feedback from them ${ }^{8}$. Due to the problems of Turkish students, who constitute the majority of the immigrant population, the Flemish authorities have indicated that they would cooperate with this process. Scientific studies based on the data obtained from pilot studies will be shared among all stakeholders.

Currently, there is a lack of bilingual education materials in Belgium, including books prepared by the Republic of Turkey Ministry of National Education for TLCL in 2018. This being the case, it is important for teachers to support existing materials bilingually. Considering the lack of available resources, it is necessary to set up the required infrastructure in order to have bilingual education in place that is compatible with that of the Flemish Region. Bilingual education should be integrated into the curriculum to promote a life-long learning process that cannot be achieved with a monolingual education programme. A lack of qualified bilingual teachers is another problem. In particular, relevant teachers need to be properly trained to fill the gap for future teachers. Teachers should be trained through the pilot schools and this process should be tailored to the training level of the local bilingual teachers.

The important basis of the bottom-up organisation model is that Turkish society makes its voice heard. For this reason, the latent reluctance and unwillingness of the participants, parents, Turkish citizens, and Turkish diaspora emerges as a major problem. In order to overcome this problem, the target groups, families and relevant stakeholders should be informed through seminars given by experts. It is also necessary to challenge the prejudice of the host country with cultural events (fun fairs, trips, commemorative ceremonies, etc.) and to organise educationally integrated activities to raise awareness. Turkish parents assume that their children know enough Turkish language and may hold the opinion that "If they learn Turkish language at school, this could be a language barrier for their Dutch language skills." In this article, it is necessary to raise awareness among Turkish families, which emphasises the importance of mother-tongue language education. To measure this demand, a data-based approach should be adopted.

In Belgium, it is necessary to put Turkish-language and culture education on a structured and institutionalised footing. An attempt has been made, within the scope of this article, to develop an institutionalised education model, which can offer a solution to the existing problem in the Flemish Region. In Belgium, Turkish-language and culture education should not be organised in a closed system where some local NGOs only target the Turkish ghetto, but in an open system that encompasses the school environment and, indeed, the society that they live in. An education disconnected from its institutional environment cannot survive in the long term. Therefore, due to the nature of education, TLCL should be taught at schools and on a basis that can provide $21^{\text {st }}$-century children skills for life-long learning. TLCL should be blended with programmes such as the Framework for 21 st Century Learning, P21 (Partnership for 21st Century Skills, 2006), which define the competence, knowledge and experience of students required to be successful in their future work and lives and should be harmonised with the society and schools in which they live. For this reason, it is very important to expand this process through schools in the Flemish Region and to develop the necessary skills among children with bilingual education programmes. With this, and similar, educational models, TLCL should be more widespread at schools.

\section{Declaration of Conflicting Interests}

The authors declared no potential conflicts of interest with respect to the research, authorship, and/or publication of this article.

\section{Funding}

This study was supported by Republic of Turkey Ministry of Culture and Tourism, Presidency for Turks Abroad and Related Communities in Turkey.

\section{Statements of publication ethics}

$1^{\text {st }}$ author conceived of the presented idea and developed the theory, performed the computations, and verified the analytical methods. $2^{\text {nd }}$ author encouraged to the $1^{\text {st }}$ author to investigate the background of the study and the literature review of the studies on bilingualism. All authors discussed the results and contributed to the final manuscript.

\section{Researchers' contribution rate}

The study was conducted and reported with $70 \%$ contribution of the first author and $30 \%$ contribution of the second author.

\section{Ethics Committee Approval Information}

We hereby declare that the study has not unethical issues and that research and publication ethics have been observed carefully.

\footnotetext{
${ }^{8}$ Based on an interview with Gonda Verhaert, General Director of Education of the Municipality of Antwerp on 7 February 2019 , and with the deputy Mayor of Antwerp, Jinnih Beels, on 1 October 2019.
} 


\section{REFERENCES}

Agirdag, O. (2010). Exploring bilingualism in a monolingual school system: insights from Turkish and native students from Belgian schools. British Journal of Sociology of Education, 31(3), 307-321.

Agirdag, O. (2016). A Deeper Analysis of The Relationship Between Language Use and Academic Achievement Using PISA 2012 Data. Paper presented at European Conference on Educational Research (ECER 2016), Dublin.

Agirdag, O. \& Vanlaar G. (2016). A hot piece of PISA: The relation between language use and academic achievement. Paper presented at Cultural Diversity, Migration, and Education conference, Potsdam, Germany.

Akoglu, G., \& Yagmur, K. (2016). First language skills of bilingual Turkish immigrant children growing up in a Dutch submersion context. International Journal of Bilingual Education and Bilingualism, 19(6), 706-721.

Akgül, D., \& Sezal, R. (2002). The Assimilationist Policies and Integration Approach in Germany. The Journal of Strategic Analysis International Relations, 3(28), August.

Altinkamis, F. (2019). Teaching Turkish as a mother tongue in Belgium: from past, to present and to future. International Journal of Language Academy, 7(27), 197-207.

Aypay, A. (2003). The relationship between State and higher education: The case of Mulkiye college in Turkey. Mediterranean Journal of Educational Studies, 8(2), 109-135.

Backus, A., \& Yagmur, K. (2019). Differences in pragmatic skills between bilingual Turkish immigrant children in the Netherlands and monolingual peers. International Journal of Bilingualism, 23(4), 817-830.

Belfi, B., Goos, M., Pinxten, M., Verhaeghe, J. P., Gielen, S., De Fraine, B., \& Van Damme, J. (2014). Inequality in language achievement growth? An investigation into the impact of pupil socio-ethnic background and school socio-ethnic composition. British Educational Research Journal, 40(5), 820-846.

Cummins, J. (1979). Linguistic interdependence and the educational development of bilingual children. Review of Educational Research, 49(2), $222-251$.

D'haeseleer, E., Smet, A. S., \& Van Lierde, K. (2016). Expressive and receptive language skills in six-year-old sequential bilingual Turkish-Dutch children compared to monolingual Dutch children in Flanders. Poster presented the International Association of Logopedics and Phoniatrics 30th World Congress.

DiMaggio, P.J. \& Powell, W.W. (1983). The Iron Cage Revisited: Institutional Isomorphism and Collective Rationality in Organizational Fields. American Sociological Review, 48, 147-60.

Meyer, J. W. \& Rowan, B. (1977). Institutionalized organizations: Formal structure as myth and ceremony. American Journal of Sociology, 83, 340-63.

Meyer, J. W., \& Scott, W. R. (1983). Organizational environments: ritual and rationality. London: Sage.

OECD (2009). International Migration: The human face of globalisation. Retrieved from http://www.oecd.org/insights/43569201.pdf on 22 April 2017.

OECD (2016). PISA 2015 Results (Volume I): Excellence and Equity in Education. Retrieved from https://www.oecdilibrary.org/docserver/9789264266490en.pdf?expires=1593789603\&id=id\&accname=guest\&checksum=0F86A187553C946C296973E0 $886 F 1141$.

Partnership for 21st Century Skills, (2006). Retrieved from http://www.p21.org/our-work/p21-framework.

PISA (2015). PISA Data on Students with an Immigrant Background. Retrieved from http://www.oecd.org/education/school/1A-Piacentini.pdf.

PISA (2018). PISA Data on Students with an Immigrant Background. Retrieved from https://www.oecd.org/pisa/data/2018database/.

Pulinx R., Van Avermaet, P. \& Agirdag O. (2016). Silencing linguistic diversity: The extent, the determinants and consequences of the monolingual beliefs of Flemish teachers. International Journal of Bilingual Education and Bilingualism.doi:10.1080/13670050.2015.1102860.

Rinker, T., Budde-Spengler, N., \& Sachse, S. (2016). The relationship between first language (L1) and second language (L2) lexical development in young Turkish-German children. International Journal of Bilingual Education and Bilingualism, 20(2), 218-233.

Sarıkaya, H.S. (2014). Examination of the basic educational problems Turkish origin children living in Belgium Flemish Region, The Journal of Academic Social Science, 2(8), 246-260.

Scott, W. R. (1991). Unpacking institutional arguments. Walter W. Powell, Paul J. DiMaggio (Eds), The new institutionalism in organizational analysis. Chicago, The University of Chicago.

Scott, W. R., \& Meyer, J. W. (1991). The organization of societal sectors: Propositions and early evidence, Walter W. Powell, Paul J. DiMaggio (eds.) in The new institutionalism in organizational analysis. Chicago, The University of Chicago.

Tolbert, P.S. (1985). Institutional environments and resource dependence: Sources of administrative structure in institutions of higher education. Administrative Science Quarterly, 30, 1-13. 
Vanbuel, M., Bodere, A., Torfs, K. \& Jaspaert, K. (2016). Vocabulary acquisition in Moroccan- and Turkish heritage children: A comparative study. International Journal of Bilingualism, 22(1), 38-50.

Yağmur, K. (2014). Turkish Children's Position in the Institutions in the Netherlands and Their Language Development. K. Iseri, G. Cetinkaya, T. Celik, S. Demirgünes, T. Dasöz, \& Y. Gencer (eds.) in Theoretical and Applied Studies in Teaching Turkish (p. 207-222). Ankara: Pegem Academy Publications.

Yıldırım, A., \& Şimşek, H. (2004). Qualitative Research Methods in Social Sciences. Ankara: Seçkin.

Yıldırım, A., \& Şimşek, H. (2005). Qualitative Research Methods in Social Sciences. Ankara: Seçkin Yayıncılık.

Yıldız, C., \& Thomas, R. (2016). Present and Future of Turkish Language in the German Education System, A Study on Turkish Lessons in Berlin, Edited: Alpaslan Okur, Bekir İnce, İsmail Güleç, Research on Teaching Turkish as a Foreign Language. Sakarya University TOMER Publications.

Yin, R. K. (2017). Case study research and applications: Design and methods. Los Angeles: SAGE. 